\title{
Faculty Perceptions Of Online Accounting Coursework
}

\author{
Amanda M. Grossman, Murray State University, USA
}

Leigh R. Johnson, Murray State University, USA

\begin{abstract}
The perceptions of faculty members, who design and evaluate online accounting coursework content, are an important consideration in determining the quality inherent in such content. This study reports the results of a survey which examines accounting faculty members' attitudes towards online education (measured as their willingness to accept transfer credit) and various contributing factors that may affect their attitudes. The results indicate that faculty members harbor significant favoritism toward accepting credit from a student with a traditional, as opposed to an online or blended learning, educational background. Additional results suggest that faculty members' previous experience with online teaching made no significant impact on their acceptance of transfer credit for the online student; however, faculty members with administrative experience were shown to be more accepting of online education. Furthermore, accounting faculty members generally consider the online educational environment to be less rigorous and less equipped to instill technical and soft skill sets than the traditional educational environment.
\end{abstract}

Keywords: Online Education; Accounting Coursework; Transfer Credit; Faculty Perceptions

\section{INTRODUCTION}

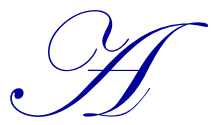

s more and more traditional universities begin to offer online business courses (Wright, 2014) due to increased pressure to expand enrollment numbers in the wake of dwindling state funding (Myring, Bott, and Edward, 2013), some institutions may consider what measures they can take to effectively compete for accounting students interested in pursuing online education. One option is to offer lowerlevel accounting courses online, specifically Principles of Accounting, in order to recruit students who would otherwise search elsewhere. A second strategy involves the acceptance of transfer credit of lower-level coursework completed at another institution regardless of the delivery method utilized in the course (e.g., online or on campus).

One issue with either solution is the potential disconnect between the perceptions of administrators who make programmatic decisions regarding online accounting coursework and the faculty responsible for the design and implementation of online programs. Research suggests that the perceptions of administrators and faculty members remain divergent along several lines, including the importance of student-instructor interactivity (Tanner, Noser, and Totaro, 2009a). Additionally, the perceptions of faculty and students differ regarding online education. Although a study by Alexander, Perreault, Zhao, and Waldman (2009) of business students and faculty demonstrated that both student and faculty member satisfaction with online education has risen, faculty members' satisfaction lags significantly behind that of students.

The present study provides an extension of prior research by examining the current trend in faculty members' perspectives regarding online accounting education. Specifically, the study examines factors involved in the willingness of accounting faculty members to accept transfer credit for lower-level accounting coursework from an Association to Advance Collegiate Schools of Business (AACSB)-accredited institution for students interested in enrolling in the members' academic institution. The study focuses on lower-level coursework since many universities are considering whether to accept such coursework for transfer credit to gain a competitive advantage with regard to enrollments. One of the most potent factors in this decision is the delivery format, or educational environment, of the transfer applicant's previous institution. To elicit comparison, three different educational 
environments are examined in this study, operationalized as follows. In the traditional educational environment, lectures and materials, as well as exams, are administered on campus. A blended learning environment can be described along a continuum of web-based activity applied in the course (Wright, 2014). Therefore, to eliminate participant confusion regarding the nature and amount of web-based activity, a hybrid educational environment, as defined in this study, is one in which lectures and materials are administered online and exams are administered on campus. Lastly, in the online environment, lectures and materials, as well as exams, are administered online.

Given the role of faculty in the development and delivery of online content, administrators should be receptive to the critiques and contributions of faculty members regarding the implementation and acceptance of online accounting coursework. Otherwise, inadequate communication and collaboration between administrators and faculty members may result in substandard distance learning education (Mosebach and Newmark, 2002). Consequently, this study can provide administrators with important information regarding accounting faculty perceptions of online coursework, allowing administration to address any issues that may limit acceptability and to determine how best to proceed in terms of communication with relevant stakeholders.

\section{HYPOTHESES DEVELOPMENT}

Despite the dramatic increase in online course offerings in recent years, faculty perceptions regarding online education have remained fairly negative during the last decade. According to a series of studies conducted by Allen and Seaman, chief academic officers surveyed believe that the preponderance of faculty at their institutions do not value or accept online courses as a legitimate delivery method $(2010,2011,2013)$. Although the Allen and Seaman studies apply to various disciplines, the results are generalizable to specific fields of study. Prior research has demonstrated that business faculty members strongly favor the traditional classroom educational environment over the online educational environment (Totaro, Tanner, Noser, Fitzgerald, and Birch, 2005; Tanner, Noser, and Totaro, 2009b); such a predisposition may also be found in examining the perception of potential employers (e.g., Kohlmeyer, Seese, and Sincich, 2011). It follows that accounting faculty would demonstrate similar preferences regarding online accounting education, including principles of accounting coursework, which is the focus of this study.

H1: Accounting faculty members will be less willing to accept principles accounting coursework credit completed in an online educational environment as opposed to either a hybrid or a traditional educational environment.

Faculty reticence to accept online coursework may be due, in part, to perceptions that the quality of online instruction is substandard to traditional methods of instruction (Seaman, 2009). In a 2010 study, Picciano, Seaman and Allen found that seventy percent of faculty respondents believed the learning outcomes of online courses to be inferior to their face-to-face counterparts. Totaro et al. (2005) note that, when compared to the traditional classroom, business faculty find numerous shortcomings with online education, including the lack of student-teacher interaction and a structured environment, the difficulty of certain subject matter and problems inherent with online assessment.

H2: Accounting faculty members will perceive the online educational environment as generally less rigorous than the traditional educational environment.

Past research has also examined a number of factors that may influence a faculty member's acceptance of online instruction. One such factor is the reputation of the academic institution offering online courses. Specifically, faculty are more receptive to online coursework when the course is offered by an accredited institution, especially those that have both online and on campus programs. Conversely, faculty lack confidence in institutions that have only online offerings (Jaschik and Lederman, 2013). Likewise, business students seeking an online degree often choose accredited, regional universities due to brand recognition (Wright, 2014). These studies emphasize the role of accreditation in evaluating the quality of distance education (Halfond, 2013). Based on these past findings, it is reasonable to expect that an institution's reputation may be of more importance to faculty members than the educational environment in which a student completed coursework.

H3: Accounting faculty members will perceive the reputation of a transfer applicant's previous educational institution as more important than the educational environment in which the applicant participated. 
Nearly two-thirds of business faculty surveyed by Totaro et al. (2005) believes that lack of student-tofaculty and student-to-student interaction in an online course could inhibit a student's educational experience, a finding supported by the 2013 Jaschik and Lederman study. Given that the development of non-technical, or soft, skills is often influenced by student interactions with faculty and other classmates, faculty acceptance of online coursework may be limited by their perception that online courses are less effective in instilling these skill sets than the traditional classroom environment. This position would be consistent with that of accounting employers who cite a perceived lack of interpersonal skills, teambuilding skills, and written and oral communication skills as one of the factors inhibiting the employment of online accounting graduates (e.g., Adams, 2008; Wagner, Hassanein, and Head, 2008).

H4: Accounting faculty members will perceive the online educational environment as more effective in imparting technical skill sets than soft skill sets.

Exposure to online courses and programs generally leads to more optimistic views regarding the online educational format. Faculty who teach online or who teach at schools with large online offerings are more positive regarding online education than their peers (Allen and Seaman, 2012; Halfond, 2013). In fact, although a preponderance of faculty in the 2009 Seaman study view learning outcomes in online courses as inferior to traditional education, a majority of faculty respondents who taught online found the learning outcomes in an online class to be the same or somewhat superior to the traditional classroom. These results are consistent with a study by Seok, DaCosta, Kinsell, and Chan (2010) which found that positive instructor perception of online course effectiveness was linked to number of years of online teaching experience.

H5: Accounting faculty members with online teaching experience will be more willing to accept online principles accounting coursework credit as opposed to accounting faculty members without online teaching experience.

In a study by Tanner et al. (2009a), business school administrators and faculty members hold different perceptions regarding the efficacy of online education. Specifically, in comparison to administrators, faculty members indicated that a higher level of instructor-student interaction exists in a face-to-face setting as opposed to an online setting. Faculty members more strongly believed that this potential lack of interaction with students in an online environment would be detrimental to learning. Additionally, faculty members were less inclined to support the future development of online courses and believed that online exams were more difficult to administer. These findings are consistent with the 2013 Allen and Seaman study in which seventy-seven percent of chief academic officers surveyed reported online learning outcomes as good or better than face-to-face instruction, although the same officers generally believe that most faculty do not value or accept the legitimacy of online courses. These studies suggest that administrators may be more receptive to online education than faculty members. By extension, those faculty members with administrative experience may be more attune to the motivations behind such administrative acceptance.

H6: Accounting faculty members with administrative experience will be more willing to accept online principles accounting coursework credit as opposed to accounting faculty members without administrative experience.

\section{METHOD}

\section{Sample}

Study participants consisted of 158 accounting faculty members from the southeast region of the country, with nine states represented. Approximately $10 \%$, however, did not provide responses past Part One of the survey. The largest percentage of participants (17\%) resided in Virginia. The majority of participants (58\%) were male and the average age was 52 years old. Only a few were not CPAs (4\%), $41 \%$ had previously taught online, and $35 \%$ had some form of administrative experience.

Participants were employed by public, four-year institutions and 90\% had an AACSB-accredited college of business. The majority of institutions (58\%) were reported to have a total student enrollment between 5,000 and 
30,000. Additionally, 56\% offer undergraduate online accounting courses and 32\% offer graduate online accounting courses. Participants reported that $83 \%$ of institutions either sometimes or usually (as opposed to never or usually not) grant transfer credit for online accounting coursework. Table 1 provides a detailed breakdown of both participant and educational institution characteristics.

Table 1: Summary Of Accounting Faculty Participant And Institutional Characteristics

\begin{tabular}{|c|c|c|}
\hline \multicolumn{3}{|l|}{ Participant Characteristics } \\
\hline Gender & Count & Percent \\
\hline Male & 91 & $58 \%$ \\
\hline Female & 52 & $33 \%$ \\
\hline No response & 15 & $9 \%$ \\
\hline Total & 158 & $100 \%$ \\
\hline Age (134 responses) & Average & Range \\
\hline & 52 & $27-74$ \\
\hline Highest Level of Education & Count & Percent \\
\hline Baccalaureate & 1 & $1 \%$ \\
\hline Graduate Degree & 35 & $22 \%$ \\
\hline Advanced Degree & 107 & $68 \%$ \\
\hline No response & 15 & $9 \%$ \\
\hline Total & 158 & $100 \%$ \\
\hline Online Teaching Experience & Count & Percent \\
\hline Yes & 65 & $41 \%$ \\
\hline No & 77 & $49 \%$ \\
\hline No response & 16 & $10 \%$ \\
\hline Total & 158 & $100 \%$ \\
\hline \multicolumn{3}{|l|}{ Administrative Experience } \\
\hline Yes & 55 & $35 \%$ \\
\hline No & 87 & $55 \%$ \\
\hline No response & 16 & $10 \%$ \\
\hline Total & 158 & $100 \%$ \\
\hline \multicolumn{3}{|l|}{ Institutional Characteristics } \\
\hline State & Count & Percent \\
\hline Alabama & 7 & $4 \%$ \\
\hline Florida & 21 & $14 \%$ \\
\hline Georgia & 15 & $9 \%$ \\
\hline Illinois & 1 & $1 \%$ \\
\hline Kentucky & 19 & $12 \%$ \\
\hline Mississippi & 14 & $9 \%$ \\
\hline North Carolina & 19 & $12 \%$ \\
\hline South Carolina & 6 & $3 \%$ \\
\hline Tennessee & 14 & $9 \%$ \\
\hline Virginia & 26 & $17 \%$ \\
\hline No response & 16 & $10 \%$ \\
\hline Total & 158 & $100 \%$ \\
\hline Size (total student enrollment) & Count & Percent \\
\hline Small $(5,000$ or less $)$ & 15 & $9 \%$ \\
\hline Medium $(5,000-30,000)$ & 90 & $58 \%$ \\
\hline Large ( 30,000 or more) & 38 & $24 \%$ \\
\hline No response & 15 & $9 \%$ \\
\hline Total & 158 & $100 \%$ \\
\hline Offers Undergraduate Accounting Online & Count & Percent \\
\hline Yes & 87 & $56 \%$ \\
\hline No & 56 & $35 \%$ \\
\hline No response & 15 & $9 \%$ \\
\hline Total & 158 & $100 \%$ \\
\hline \multicolumn{3}{|l|}{ Offers Graduate Accounting Online } \\
\hline Yes & 52 & $32 \%$ \\
\hline No & 89 & $57 \%$ \\
\hline No response & 17 & $11 \%$ \\
\hline Total & 158 & $100 \%$ \\
\hline
\end{tabular}




\section{Data Collection}

Accounting faculty participants were contacted through email and provided a hyperlink to begin a 10minute online survey, which consisted of three parts. In Part One, participants were directed to consider three student applicants who were interested in enrolling in the participants' educational institution. All three applicants had previously attended a four-year educational institution, whose college of business was accredited by the AACSB. The applicants currently had accumulated 45 credit hours, including three credit hours from a course entitled "Managerial Accounting Principles." Each applicant earned an "A" in the course and participants were instructed to assume that the course content was comparable to that in their own managerial principles course. However, each applicant's course was completed in one of three different educational environments: traditional, hybrid, or online. For each applicant, participants responded to the question, "Do you believe your institution should be willing to grant transfer credit?" A Likert scale from 1 (not at all willing) to 7 (extremely willing) was employed. Next, participants were asked, for each of the three applicants, how their willingness evaluation may change if the applicant's previous educational institution was (1) not accredited by the AACSB, but by another body such as SACS (Southern Association of Colleges and Schools), (2) a two-year college, and (3) not accredited by any professional body. Another Likert scale from 1 (less willing to grant credit) to 7 (more willing to grant credit) was utilized.

In Part Two, participants were asked to rate the importance of a transfer applicant's previous educational environment (traditional, hybrid, or online) as well as the importance of the previous institution's reputation. A Likert scale from 1(not at all important) to 7 (extremely important) was used. Participants were then asked their perception of the general rigor of the online educational environment as opposed to that of the traditional educational environment. The scale employed ranged from 1 (much less rigorous) to 7 (much more rigorous). Next, participants indicated their perception of the effectiveness of the online educational environment in instilling both technical and soft (oral communication, written communication, team-building, and interpersonal) skill sets. Each skill was rated on a scale from 1 (extremely ineffective) to 7 (extremely effective). Finally, participants were asked to indicate which accounting courses may be best suited to the online educational environment (participants deemed each course as either suited or not suited). Free-form comments regarding participant sentiments toward online education were also captured.

In Part Three, participants responded to a series of demographic questions, including age, gender, highest level of education, and professional certifications. Participants were also asked whether or not they had taught online accounting courses and if they had ever been involved in an administrative role at their educational institution. Finally, participants were asked to rate how influential their opinion is in determining the suitability of granting accounting coursework transfer credit on a scale from 1 (not at all influential) to 7 (extremely influential). Information regarding participants' educational institution was also gathered, including whether or not undergraduate and/or graduate accounting courses were offered online, the state in which the institution is located, its size, and its accreditation status.

\section{RESULTS}

\section{Hypotheses Testing}

The first hypothesis stipulated that accounting faculty members would be less willing to approve transfer credit for an accounting principles course taken in an online educational environment than in either a hybrid or traditional environment. To examine this supposition, a repeated-measures test was conducted among the three levels of educational environment. The results demonstrate that faculty members would indeed be significantly less willing to grant transfer credit to an online student $($ mean $=4.03)$ as opposed to either a hybrid $($ mean $=5.69)$ or a traditional $($ mean $=6.52)$ student $(\mathrm{F}(2,314)=166.318, \mathrm{p}=.000)$. Table 2, Panel A, provides the statistical result for the repeated-measures test. Within-subjects contrast testing further indicates that all three levels of educational environment were statistically different from one another. These results provide support for H1. Interestingly, although faculty members clearly prefer the traditional or the hybrid student over the online student, the willingness rating for this student is not statistically different than the neutral value of 4 employed on the measurement scale (see Table 3). Thus, it appears that faculty members are either neutral, or indifferent, in their willingness to accept lower-level online accounting coursework for transfer credit. 
Table 2: Repeated-Measures Tests Results

\begin{tabular}{|c|c|c|c|c|}
\hline \multicolumn{5}{|c|}{ Panel A: Willingness to Grant Transfer Credit by Educational Environment } \\
\hline Within-Subjects Effects & MS & df & $\mathbf{F}$ & Sig \\
\hline Educational Environment (Traditional, Hybrid, or Online) & 253.432 & 2 & 166.318 & .000 \\
\hline Error & 1.524 & 314 & & \\
\hline \multicolumn{5}{|c|}{ Panel B: Effectiveness of Online Environ. In Imparting Skills } \\
\hline Within-Subjects Effects & MS & df & $\mathbf{F}$ & Sig \\
\hline Skills (Technical, Written, Oral, Team-Building, Inerpersonal) & 108.408 & 4 & 113.824 & .000 \\
\hline Error & 0.952 & 564 & & \\
\hline
\end{tabular}

The second hypothesis examines accounting faculty members' perception of the rigor of the online educational environment. Using a one-sample t-test, their ratings of the general rigor of the online environment, as compared to the traditional environment, were evaluated against the neutral rating of 4 . Results indicate that faculty members consider the online educational environment significantly inferior (mean $=2.69$ ) to the traditional educational environment $(\mathrm{t}(143)=-12.288 ; \mathrm{p}=.000)$. This result provides support for H2. Table 3 provides onesample t-tests, comparing all dependent measurements against the neutral scale rating of 4.

Table 3: Dependent Measurements Tested Against Neutral Value Of 4

\begin{tabular}{|c|c|c|c|c|}
\hline Measurement & Mean & df & t-value & Sig \\
\hline Willingness to Grant Transfer Credit in Traditional Environment & 6.52 & 157 & 35.144 & .000 \\
\hline Willingness to Grant Transfer Credit in Hybrid Environment & 5.69 & 157 & 15.528 & .000 \\
\hline Willingness to Grant Transfer Credit in Online Environment & 4.03 & 157 & 0.194 & .846 \\
\hline Rigor of Online Education & 2.69 & 143 & -12.288 & .000 \\
\hline Importance of Previous Educational Environment & 4.90 & 142 & 6.589 & .000 \\
\hline Reputation of Previous Educational Institution & 5.69 & 143 & 15.335 & .000 \\
\hline Technical Skills in Online Environ. & 4.03 & 143 & 0.203 & .839 \\
\hline Written Communication Skills in Online Environ. & 4.27 & 143 & 2.144 & .034 \\
\hline Oral Communication Skills in Online Environ. & 2.33 & 142 & -13.807 & .000 \\
\hline Team-Building Skills in Online Environ. & 3.06 & 142 & -7.036 & .000 \\
\hline Interpersonal Skills in Online Environ. & 2.53 & 143 & -11.632 & .000 \\
\hline Willingness to Grant Online Transfer Credit (with Online Teaching Experience) & 4.31 & 64 & 1.231 & .223 \\
\hline Willingness to Grant Online Transfer Credit (without Online Teaching Experience) & 3.86 & 76 & -.606 & .546 \\
\hline Willingness to Grant Online Transfer Credit (with Administrative Experience) & 4.42 & 54 & 1.553 & .126 \\
\hline Willingness to Grant Online Transfer Credit (without Administrative Experience) & 3.80 & 86 & -.874 & .384 \\
\hline Influence in Determining Suitability of Transfer Credit & 3.85 & 142 & -.992 & .323 \\
\hline
\end{tabular}

The third hypothesis proffered that institutional reputation was of greater importance to faculty members than educational environment in their willingness to accept transfer credit. A dependent t-test (see Table 4) was used to evaluate participant responses and produced a significant result $(\mathrm{t}(142)=5.679, \mathrm{p}=.000$, one-tailed). In support of $\mathrm{H} 3$, faculty members were indeed more concerned with the reputation of the transfer applicant's previous institution (mean $=5.69)$ over the educational environment in which the applicant participated $($ mean $=4.90)$.

Table 4: Dependent And Independent T-Test Results

\begin{tabular}{|c|c|c|c|c|c|}
\hline Dependent Measure & $\begin{array}{c}\text { Institutional } \\
\text { Reputation Mean }\end{array}$ & $\begin{array}{c}\text { Educational } \\
\text { Environ. Mean }\end{array}$ & t-stat. & df & Sig. \\
\hline \multirow[t]{2}{*}{ Importance } & 5.69 & 4.90 & 5.679 & 142 & .000 \\
\hline & $\begin{array}{c}\text { Online Teaching } \\
\text { Experience Mean }(\mathbf{N})\end{array}$ & $\begin{array}{l}\text { No Online Teaching } \\
\text { Experience Mean }(\mathrm{N})\end{array}$ & & & \\
\hline \multirow[t]{2}{*}{ Willingness to Grant Online Transfer Credit } & $4.31(65)$ & $3.86(77)$ & 1.308 & 140 & .097 \\
\hline & $\begin{array}{c}\text { Administrative } \\
\text { Experience Mean }(\mathbf{N})\end{array}$ & $\begin{array}{c}\text { No Administrative } \\
\text { Experience Mean (N) }\end{array}$ & & & \\
\hline Willingness to Grant Online Transfer Credit & $4.42(55)$ & $3.80(87)$ & 1.736 & 140 & .043 \\
\hline
\end{tabular}


To evaluate the fourth hypothesis, a repeated-measures test (see Table 2), as well as individual one-sample t-tests (see Table 3), were employed to examine perceptions of the online educational environment to impart the following skill sets: technical, oral communication, written communication, team-building, and interpersonal. The results from the repeated-measures test, provided in Panel $\mathrm{B}$ of Table 2, indicate that a distinction is made among the skill sets $(F(4,564)=113.824 ; \mathrm{p}=.000)$. A Bonferroni post-hoc analysis reveals that the effectiveness ratings for technical skills (mean $=4.03$ ) and written communication skills $($ mean $=4.27)$ were not significantly different from one another; however, these ratings were significantly different from oral communication skills $($ mean $=2.33)$, team-building skills $($ mean $=3.06)$ and interpersonal skills $($ mean $=2.53)$. These results do not provide support for $\mathrm{H} 4$, as written communication skills were rated slightly higher than technical skills. Although technical and written communication skills were rated significantly higher than all other examined skill sets, only written communication skills were rated significantly higher than the neutral rating of 4 . These data, taken together, clearly indicate that faculty members find the online educational environment unequal to the task of imparting either technical or soft skills sets to students.

The fifth hypothesis explored the potential relationship between faculty members' experience with teaching online and their willingness to accept transfer credit from the online student. An independent $t$-test $(t(140)=1.380, p$ $=.097$, one-tailed) indicated that those faculty members with online teaching experience $($ mean $=4.31)$ were no more accepting of the transfer credit than those faculty members without online teaching experience (mean $=3.86$ ). Such results do not support H5 (see Table 4). However, since the means provided by both groups are not significantly different from the neutral value of 4 (see Table 3), it appears that neither is eagerly accepting of online transfer credit.

The sixth hypothesis posits that accounting faculty members with administrative experience will be more inclined to accept transfer credit obtained in an online educational environment than faculty members without such experience. An independent t-test was employed to examine this claim (see Table 4). The findings demonstrate that those faculty members with administrative experience (mean $=4.42$ ) were more willing than those faculty members without administrative experience (mean $=3.80)$ to accept transfer credit from an online applicant $(\mathrm{t}(140)=1.736 ; \mathrm{p}$ $=.043$, one-tailed). While the results provide support for H6, it must be noted that both groups did not indicate favoritism in accepting such credit, as their ratings were insignificantly different from the neutral ratings mark (see Table 3). Further analyses indicate that faculty members do not consider themselves influential in the determination of transfer credit acceptance (see Table 3). If garnering acceptance for online transfer credit is a university's goal, perhaps it should consider fostering a more inclusive atmosphere between administrators and faculty.

\section{Additional Analyses}

In reference to the first hypothesis, which asked faculty participants to rate their willingness to grant transfer credit to an applicant who received his or her education at an AACSB-accredited institution, three variations were examined. The first variation asked participants how their rating might change if the previous institution were not accredited by the AACSB, but by SACS. The second variation asked how participants' ratings might change if the previous institution were a two-year college, and the third variation explored rating changes if the previous institution was not accredited at all. For each educational environment (traditional, hybrid, and online), a repeatedmeasure test was employed to capture the four different aforementioned ratings. In all three educational environments, the same pattern emerged. An AACSB-accredited institution significantly outperformed all other variations and no significant differences arose between a SACS-accredited institution and a two-year college. A non-accredited institution was held in very poor esteem, regardless of educational environment. Insofar as the willingness to grant transfer credit, it appears that an AASCB accreditation sets the standard. Figure 1 provides a visual representation of the effects of institutional accreditation throughout the three levels of the educational environment. 


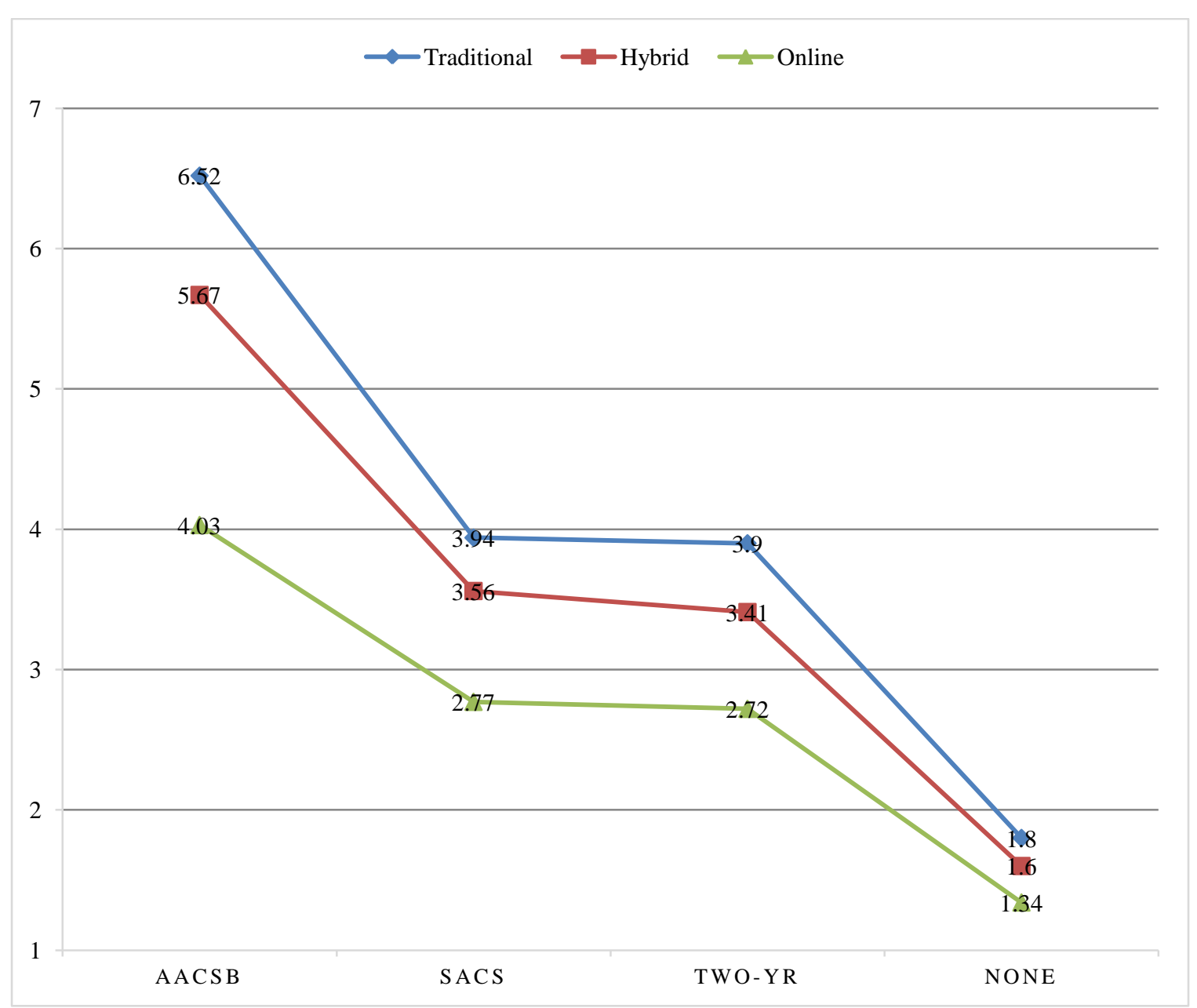

Figure 1: Effect Of Accreditation Status On Willingness To Grant Transfer credit

Study participants were also asked to indicate which accounting courses may be effectively taught in an online educational environment. Table 5 presents the results of their "yes" or "no" responses. These data show that only principles courses enjoy any substantial support from accounting faculty members as suited to the online educational environment.

Table 5: Faculty Members' Decision On Effectiveness Of Online Education For Accounting Curriculum

\begin{tabular}{lcc}
\hline \multicolumn{1}{c}{ Course } & Can Be Taught Online & Cannot Be Taught Online \\
\hline Accounting Principles & $67 \%$ & $33 \%$ \\
Intermediate Accounting & $25 \%$ & $75 \%$ \\
Cost Accounting & $33 \%$ & $67 \%$ \\
Tax & $35 \%$ & $65 \%$ \\
Accounting Information Systems & $33 \%$ & $67 \%$ \\
Auditing & $24 \%$ & $76 \%$ \\
Advanced Accounting & $23 \%$ & $77 \%$ \\
\hline
\end{tabular}

Fifty-one study participants provided free-form comments on online education. These comments were analyzed for common themes and five emerged. Most frequently, participants commented on the potential lack of integrity (i.e., cheating) inherent in an online delivery format. Secondly, participants were concerned that the rigor provided in a traditional classroom was absent in an online setting. Third, some participants believed that online delivery may be an effective means of learning, but that effectiveness depends upon the motivation of the student enrolled. Fourth, some participants believed that most accounting courses could be taught online effectively, but the 
faculty member's training and skill was a determinant factor. Of the few remaining comments, some were centered on the lost benefits of in-person communication and others indicated that online education may be preferable only for lower-division coursework (such as principles). Table 6 provides a breakdown of comment themes and exemplar comments from participants.

Table 6: Accounting Faculty Participant Comment Exemplars On Online Education By Themes

\begin{tabular}{|c|c|c|}
\hline Theme & Count & Exemplar \\
\hline Integrity & 16 & $\begin{array}{l}\text { "Exams should not be given online. There is too much opportunity to cheat and it is not an } \\
\text { effective way of assessing what a student has learned." }\end{array}$ \\
\hline Rigor & 13 & $\begin{array}{l}\text { "I think a classroom is a valuable part of the educational process and will never be } \\
\text { replaced by an online class. My perception of online classes is that they will require far } \\
\text { more time to complete than a traditional class that covers the same level of material. I have } \\
\text { seen a number of online courses that I view as watered down versions of the real class." }\end{array}$ \\
\hline $\begin{array}{l}\text { Student } \\
\text { Motivation }\end{array}$ & 8 & $\begin{array}{l}\text { "It is the student's desire to learn, and consequently, the amount of time a student is } \\
\text { willing to invest that is important." }\end{array}$ \\
\hline $\begin{array}{l}\text { Faculty } \\
\text { Training/Skill }\end{array}$ & 7 & $\begin{array}{l}\text { "Online accounting courses can be effectively taught with the proper pedagogical } \\
\text { techniques, including synchronous and asynchronous discussions, group assignments, } \\
\text { frequent interactions with the course instructor, and multiple active learning activities. It } \\
\text { takes a LOT of work, possibly more work than traditional classroom requirements, but it } \\
\text { can be done." }\end{array}$ \\
\hline $\begin{array}{l}\text { Course } \\
\text { Level/Other }\end{array}$ & 7 & $\begin{array}{l}\text { "The technical nature of accounting makes it very difficult to deliver accounting in an } \\
\text { online format especially as the material becomes more advanced. Basic accounting skills } \\
\text { can be delivered effectively in an online format, however the more advanced content } \\
\text { requires two-way communication that is available in face-to-face courses." }\end{array}$ \\
\hline
\end{tabular}

\section{SUMMARY AND CONCLUSIONS}

This study examined the perceptions of accounting faculty members toward online education, primarily by capturing how willing they believe their educational institution should be in granting credit to a transfer student applicant. For a transfer student who received an "A" in an accounting principles course from an AACSB-accredited institution, faculty members were, not surprisingly, overwhelmingly willing to support granting transfer credit. However, this was only the case when the transfer applicant's coursework was obtained in a traditional educational environment. If the coursework was obtained in a hybrid educational environment (blended learning), the willingness significantly dropped, and if the coursework was obtained in an online educational environment, willingness significantly dropped again - but only to the point of indifference. Such results imply that faculty members are not necessarily opposed to granting transfer credit to a student with online coursework.

While a change in the educational environment did not lead faculty members to balk at granting transfer credit, more varied results arose with other-than-AACSB-accredited institutions. When the applicant's previous institution was either accredited by another body, such as SACS, or a two-year college, accounting faculty members were relatively indifferent between these two options. Overall, however, moving away from an AACSB accreditation status in any educational environment dropped the faculty members' ratings. Therefore, an online student from an other-than-AACSB-accredited institution was viewed negatively, as opposed to only indifferently. Also not surprisingly, when the institution was not accredited, faculty members clearly were disinterested in considering the transfer student, regardless of the educational environment.

Somewhat disconcertingly, although faculty members are not vehemently opposed to their institution offering transfer credit to an online student, they do not appear to place any confidence in an online educational format to equip the student with necessary technical and soft skill sets. Participant comments indicate that faculty members are highly concerned with potential breaches in the integrity of an online course (i.e., methods of cheating), faculty training and preparedness to administer online coursework, individual student motivation, and the general rigor inherent in such coursework. These, and no doubt other factors, need to be continually re-examined in light of the online educational environment. Perhaps the disconnect lies in faculty members' recognition that online education will only expand, and a greater percentage of incoming students will be a product of online education. 
Other study results determined that accounting faculty members with online teaching experience were no more apt to support granting transfer credit to the online student than those faculty members without online teaching experience. Apparently, familiarity with the methodology does not yield more confidence in its effectiveness. On the other hand, faculty members with administrative experience were more apt than those without such experience to support the granting of transfer credit. A different perspective, perhaps from the standpoint of running the university as a business, appears to slightly alter faculty members' position on the subject.

This study purposefully examined perceptions on granting transfer credit for principles-level coursework. In that vein, faculty participants viewed principles' content as the only subject matter which may lend itself toward effective instruction in an online environment. However, it must be noted that some state legislatures (e.g., Kentucky) compel state universities to accept transfer credit from community colleges, potentially subverting the issue of quality in online programs offered. One study participant offered the following explanation and opinion on the subject: Our institution has a system-wide agreement with the community college system to accept a large number of courses for transfer. We have no choice, so it doesn't matter how effective or what the delivery means was, if it is on the list, we accept it. I know of several community colleges that do a poor job in teaching principles even face-face but it still doesn't matter. I believe that some students can do very well with an online class and I know several instructors who do a great job with their online classes, but they are the exception rather than the rule. For many, online is just the new version of correspondence courses. Our accounting online classes require proctored exams, but we are one of the few departments to require them.

\section{AUTHOR INFORMATION}

Dr. Amanda M. Grossman has been an instructor at Murray State University since receiving her doctorate from Southern Illinois University Carbondale in 2007. Her published research includes articles in Advances In Accounting, Behavioral Research In Accounting, the International Journal of Accounting, Auditing and Performance Evaluation, and the Journal of Corporate Taxation. Email: agrossman@murraystate.edu.

Dr. Leigh R. Johnson obtained her JD from the University of Kentucky's College of Law where she graduated in 2002. Prior to joining Murray State University in 2006, she was a corporate and securities associate at Womble Carlyle Sandridge \& Rice, PLLC in North Carolina. Her published research includes articles in The Journal of Accounting, Ethics, and Public Policy, The Journal of Corporate Taxation, The Journal of Corporate Accounting and Finance, and The U. C. Davis Business Law Journal. Email: 1johnson1@murraystate.edu.

\section{REFERENCES}

Adams, J. (2008). Understanding the factors limiting the acceptability of online courses and degrees. International Journal on E-Learning, 7(4): 573-587.

Allen, I. E., \& Seaman, J. Babson Survey Research Group. (2010). Learning on demand, online education in the United States, 2009. Retrieved from http://www.onlinelearningsurvey.com/reports/learning-on-demand.pdf.

Allen, I. E., \& Seaman, J. Babson Survey Research Group. (2011). Going the distance, online education in the United States, 2011. Retrieved from http://www.onlinelearningsurvey.com/reports/goingthedistance.pdf.

Allen, I. E., \& Seaman, J. Babson Survey Research Group. (2012). Conflicted: faculty and online education, 2012. Retrieved from http://www.insidehighered.com/sites/default/server_files/survey/conflicted.html.

Allen, I. E., \& Seaman, J. Babson Survey Research Group. (2013). Changing course: ten years of tracking online education in the United States. Retrieved from http://www.onlinelearningsurvey.com/reports/changingcourse.pdf.

Alexander, M. W., Perreault, H., Zhao, J. J., \& Waldman, L. (2009). Comparing AACSB faculty and student online learning experiences: changes between 2000 and 2006. The Journal of Educators Online, 6(1), 1-19.

Halfond, Jay. (2013). Wallflowers at the revolution: evolving faculty perspectives on online education. The New England Journal of Higher Education. Retrieved from http://www.nebhe.org/thejournal/wallflowers-atthe-revolution-evolving-faculty-perspectives-on-online-education/.

Jaschik, S., \& Lederman, D. (2013). Inside Higher Ed. The 2013 inside higher ed survey of faculty attitudes on technology. Retrieved from https://www.insidehighered.com/news/survey/survey-faculty-attitudestechnology. 
Kohlmeyer, J. M., Seese, L. P., \& Sincich, T. (2011). Online versus traditional accounting degrees: perceptions of public accounting professionals. Advances in Accounting Education: Teaching and Curriculum Innovation, $12,139-165$.

Mosebach, M., \& Newmark, R. I. (2002). Accounting faculty members' perceptions of distance learning: an exploratory study. Distance Education Online Symposium News, 12(2).

Myring, M., Bott, J. P., \& Edwards, R. (2013). New approaches to online accounting education. Retrieved from http://nasba.org/files/2013/08/Online-Accounting-Education-RR-Preliminary-Draft.pdf.

Picciano, A., Seaman, J., \& Allen, I. E. (2010). Educational transformation through online learning: to be or not to be. Journal of Asynchronous Learning Networks, 14(4), 17-35.

Seaman, J. Association of Public and Land-grant Universities-Sloan National Commission on Online Learning. (2009). Online learning as a strategic asset: volume II. Retrieved from http://sloanconsortium.org/publications/survey/APLU_Reports.

Seok, S., DaCosta, B., Kinsell, C., \& Tung, C. K. (2010). Comparison of instructors' and students' perceptions of the effectiveness of online courses. Quarterly Review of Distance Education, 11(1), 25-36.

Tanner, J. R., Noser, T. C., \& Totaro, M. W. (2009a). Business school administrators' and faculty perceptions of online learning: a comparative study. Issues in Innovation. Retrieved from http://www.thefreelibrary.com/Business+school+administrators'+and+faculty+perceptions+of+online...a0224249886.

Tanner, J. R., Noser, T. C., \& Totaro, M. W. (2009b). Business faculty and undergraduate students' perceptions of online learning: a comparative study. Journal of Information Systems Education, 20(1), 29-40.

Totaro, M. W., Tanner, J. R., Noser, T., Fitzgerald, J. F., \& Birch, R. (2005). Faculty Perceptions of Distance Education Courses: A Survey. Journal of College Teaching and Learning, 2(7), 13-20.

Wagner, N., Hassanein, K., \& Head, M. (2008). Who is responsible for e-learning success in higher education? A stakeholders' analysis. Educational Technology \& Society, 11(3), 26-36.

Wright, K. (2014). The trouble with online undergraduate business degrees in traditional regional universities. Journal of College Teaching and Learning, 11(1), 13-24. 
NOTES 